\title{
A Survey of Weaver-birds' Crop-raiding Behavioral Activity in Buea Municipality, Southwest Region, Cameroon
}

\author{
Melle Ekane Maurice ${ }^{1, ~ *, ~ K a t o ~ S a m u e l ~ N a m u e n e ~}{ }^{1}$, Ewane Divine ${ }^{1}$, Mbole Veronique ${ }^{1}$, \\ Agborta Sylvie Oyong ${ }^{2}$ \\ ${ }^{1}$ Department of Forestry and Wildlife, Faculty of Agriculture and Veterinary Medicine, University of Buea, Buea, Cameroon \\ ${ }^{2}$ Mvog-Betsi Zoo, Yaounde, Cameroon \\ Email address: \\ melleekane@gmail.com (M. E. Maurice), melle.ekane@ubuea.cm (M. E. Maurice) \\ ${ }^{*}$ Corresponding author
}

To cite this article:

Melle Ekane Maurice, Kato Samuel Namuene, Ewane Divine, Mbole Veronique, Agborta Sylvie Oyong. A Survey of Weaverbirds' Crop-raiding Behavioral Activity in Buea Municipality, Southwest Region, Cameroon. Plant.

Vol. 8, No. 4, 2020, pp. 108-114. doi: 10.11648/j.plant.20200804.14

Received: November 1, 2020; Accepted: November 16, 2020; Published: November 24, 2020

\begin{abstract}
The entire surface of the earth is visited by the birds in view of their aerial flights and variable habitats in search of suitable breeding and feeding grounds. Flight, intelligence, adaptability and sight are some of the attributes that add to the diversity in the life of birds, consequently there is complexity in their overall behavioral pattern. The key objective of this study was to assess the weaver-bird crop-raiding activity in Buea municipality on different environmental parameters. The study was undertaken for three months, six days in a week, from 7:00am to 6:00pm. Scan observations were made on birds' activity on a five-minute interval period across the entire study area. Simultaneously, data was collected on the environmental conditions. The study recorded a significant association between weaver-bird activity on crop-land, $\mathrm{X}^{2}=11.653 \mathrm{df}=14, \mathrm{P}<$ 0.005 and $\mathrm{X}^{2}=3.441 \mathrm{df}=4, \mathrm{P}<0.05$ respectively. There was weaver-bird activity frequency of $51.63 \%, 45.35 \%$, and $3.02 \%$ for Ploceus luteolus, Ploceus cuculatus, and Ploceus melanocephalus respectively. Moreover, a week association between bird activity and weather, $\mathrm{X}^{2}=3.125 \mathrm{df}=3, \mathrm{P}<0.05$ was recorded. The sunny and cloudy weather conditions recorded $53.26 \%$, and $42.09 \%$ respectively, while the windy and rainy weather conditions were significantly low (3.26\%). An association was recored between atmospheric conditions and weaver-birds' activity on crops, $\mathrm{X}^{2}=23.249 \mathrm{df}=21, \mathrm{P}<0.05$. In addition, the most destroyed farms were Elaeis guineensis (32.33\%), Saccharum officinarum (19.77\%), Zea mays (17.44\%), and Mangifera indica (15.58\%) respectively, and the scale of destruction was very prominent on the foliage used by the birds for nest-building. Maize crops and oil-palms were among the crop species most subjected to destruction by birds. These crops were observed with poor foliage formation and fruits, consequently they withered, and since the local farming population in this municipality predominantly cultivate these crops most, a heavy toll is often taken on the annual farmers' income.
\end{abstract}

Keywords: Feeding, Nesting, Weaver-bird, Environmental Conditions, Crops

\section{Introduction}

The world population continues to grow, accompanied by rapid urbanization and industrialization. In 2009, more than $50 \%$ of the world's population was living in cities [48], with the most rapid urban growth in low income regions. In Africa the urban population is likely to triple, and in Asia it will be more than double in a few decades [48]. Loss of biodiversity is a worldwide phenomenon [8]. Even though cities only occupy $2.7 \%$ of the world's dry-lands, urbanization leads to several environmental problems including damage to biodiversity [26, 22]. Birds are globally seen as a flagship group for conservation, ecological and evolutionary reasons, and they occupy a significant place in people's perception of nature. Birds are highly sensitive as well as mobile, and thus eminently suitable to study the impact of anthropogenic disturbance on biodiversity $[9,20]$.

The historical legacy of a landscape, which includes human traditions, patterns of disturbance, succession, and plant and animal use or introductions, strongly affects current biodiversity and prospects for restoration or change [51]. In 
that regard, current bird populations in agro-ecosystems reflect the land and agricultural history of the area. Agricultural history dates back over 10,000 years [40, 34] and humans have had today's domesticated crops, animals, and basic tools such as the plough, hoe, sickle, harrow, and axe for over 2,500 years [7]. In Europe, agriculture has been present for about 9,000 years [40] and pigs and dairying for about 6,000 [44, 29].

Much of Great Britain has been farmed for over 5,000 years with subsequent clearing events $(\sim 4,700$ and 2,230 years ago) and most of the landscape has been organized for intense agricultural use for over 1,000 years $[50,17]$. In the Americas, maize and other crops were under cultivation in Mexico about 8,700 years ago [32,35] and, in eastern North America, domesticated plants appeared about 5,000 years ago [33], crop complexes 3,800 years ago, and maize about 2,200 years ago [42].

Before European colonization of the Americas, however, agriculture was mixed with hunting-gathering activities and overall land-use pressure was less intense than in Europe [42, 15]. With the long-term intense use of land in Great Britain and parts of Europe, birds that remain in farming systems are now collectively known as farmland birds and conservation efforts are primarily through agri-environmental policies focused within and around farm fields [50, 52]. In the Americas, birds in agro-ecosystems are still associated primarily with their native habitat types and consequently are managed by their primary habitat preference. In Europe, the United States, and Canada most clearing of new land has stabilized. There, conservation efforts associated with farming are primarily focused on soil and water and thus attempt to discourage planting row crops on highly-erodible land and encroachment on remaining natural habitats such as riparian areas or wetlands. Although benefits to wildlife are generally secondary outcomes, the habitat value of mid-term (10-15 years) set-aside areas to declining grassland birds is a recognized benefit of government programs [24].
Finally, in tropical areas where agricultural intensification is more recent, additional clearing of forest land for crops or pasture is a major concern, especially in parts of South America (especially Brazil), sub-Saharan Africa, and Indonesia [23]. The history and legacy of various global areas affect decisions about farming and bird habitats. These are reflected in the accounts of the geographical areas that follow below, beginning with Europe, followed by the United States and Canada, and then Latin America, three areas that represent a range of agricultural management patterns and impacts on bird populations.

As agricultural expansion and intensification increased and the associated impacts on birds and other biodiversity became more apparent, research began to focus on understanding how bird populations might be conserved within farmland [2, 49]. Currently, a key global question facing society is how to produce needed food, fiber, and energy while sustaining bird populations and other biodiversity $[16,28]$. The need in part is to understand how birds interface with agro-ecosystems, how they are affected by associated management practices, and what conservation approaches might reduce negative impacts.

Studies of the structural properties of nest materials are rare $[41,5,4]$, so little is known about whether birds are generally selective of nest materials based on their biomechanical properties. Weaver-birds are crop-raiders in Cameroon and other countries in sub Saharan Africa. Their prolific reproductive behavior has given them the ability to invade crop-farmland in hug numbers, the reason crop farmers in most areas in Cameroon suffer annual crop-yield shortages. The crop-raiding behavior of weaver-birds also involves nest-building in the farming areas for breeding. This characteristic is the main reason their destruction on cropfarms is heavy and takes an annual income toll on its victims. Hence, this study was focused on the birds' destructive feeding and nesting activities on farm crops in Buea municipality.

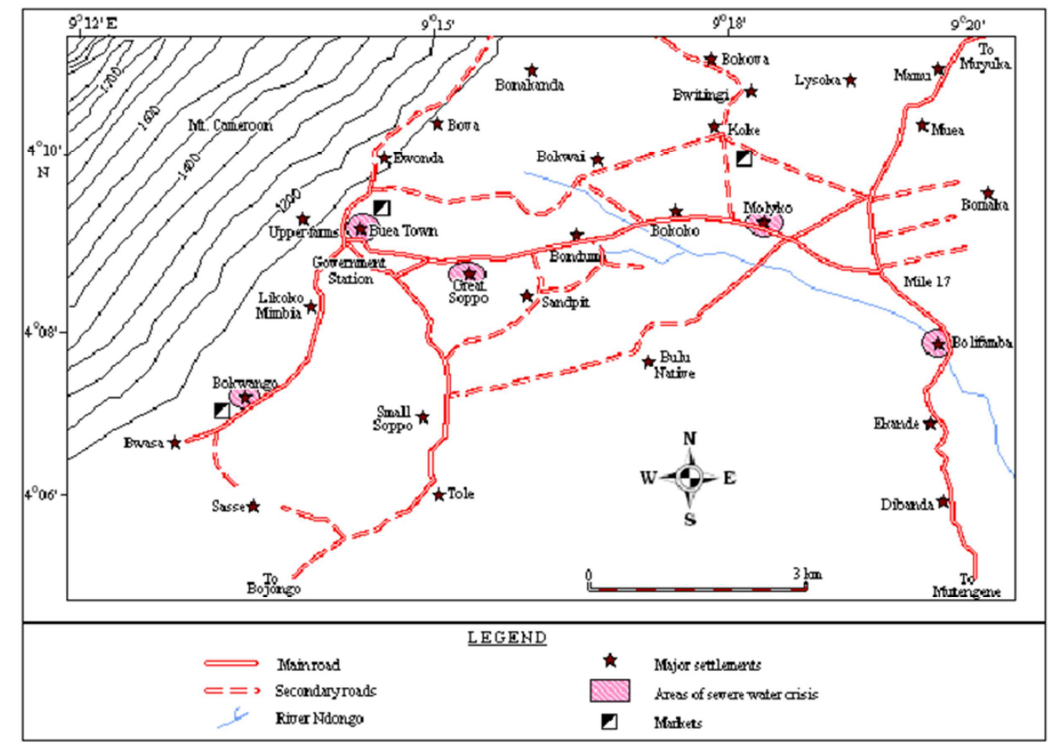

Figure 1. Map of Buea Municipality. 


\section{Materials and Methods}

\subsection{The Description of Study Area}

Buea municipality is found in the Southwest Region of Cameroon, located between longitude $9^{0} 16^{\prime} \mathrm{E}$ and latitude $4^{0} 9^{\prime}$ $\mathrm{N}$ (figure 1) [46, 14]. The municipality is bounded to the north by tropical forest on the slope of mount Cameroon $(4100 \mathrm{~m}$ above sea level). The population is estimated at about 300,000 people, of whom two-third live in the city of Buea, while the rest in villages. The settlement pattern forms a closed ring around the foot of the mountain with no permanent settlements on altitudes above $1500 \mathrm{~m}$. The indigenous people in the area are Bakweri, Bomboko, Balondo and Bakolle [11]. With an equatorial climate, temperature is moderate with a slight seasonal variation (rainy and dry season) [46]. The region is also very diverse in fauna with over 370 species of wildlife recorded. The sub-montane and montane habitats are part of Cameroon mountain endemic bird area. So far, 210 species of birds have been recorded, out of which 8 are threatened and 2 strictly endemic mount cameroon francolin (Francolinus camerunensis) and mount cameroon speirops (Speirops melanocephalus) [11]. Agriculture is the most important source of livelihood in the area accounting for about $80 \%$ of household income in most villages [31]. Other sources of income include hunting, timber and non-timber forest products (NTFP) exploitation, petty trading, and cattle rearing [46].

\subsection{Data Collection Method}

The research data collection program was done by a research team made up of four persons, the principal investigator and three other student colleagues. The threemonth study was carried out in Buea municipality, and the research data was collected between 7:00am - 6:00pm each day of the study, and was done 6 days each week, Monday Saturday. The team visited all the neighborhoods of the city on a daily bases to record observations on bird species, feeding activity, locations, and day-period. A five-minutespot-count method was used throughout the data collection period [38]. Point counts (where the observer is sedentary at one place), is among the most frequently used techniques for monitoring terrestrial birds [39]. Bird population monitoring programs vary in how they are conducted. The Breeding Bird Survey (BBS), for example, is run in Britain and variants of it are used by 18 other European countries [45]. Five-minute point-based distance counts are used in France that specify the area of the sampling site and the distance bands used around each point, $(<25 \mathrm{~m}, 25-100-\mathrm{m}$, and $>100-\mathrm{m})$ [45].

\subsection{Data Analysis}

The research data collected on check-sheets was analyzed by the use of SPSS version 20. And the main statistical model used was chi-square to test the relationships existing between the variables such as bird species, bird feeding and nesting activities, and the neighborhood location. Exploratory analysis was used to further examine the frequency of variables like bird activity, environmental condition, and bird species

\section{Results}

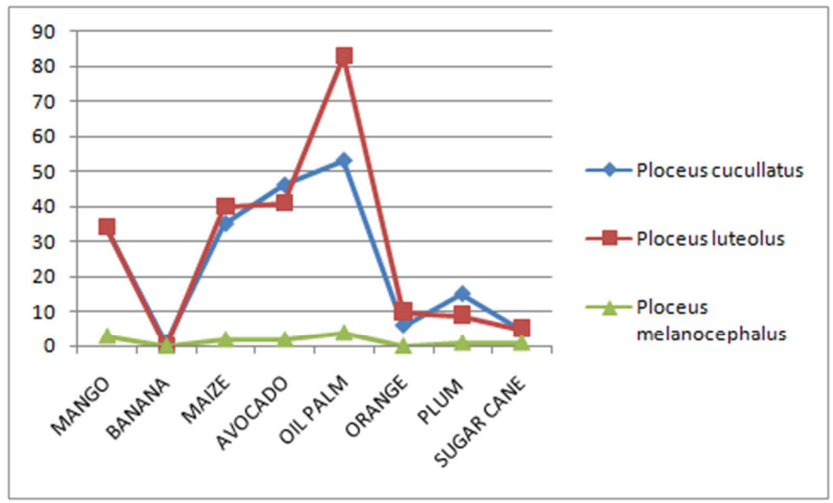

Figure 2. Weaver birds and agriculture.

The study recorded a significant association between weaver-birds activity on crop-land, $\mathrm{X}^{2}=11.653 \mathrm{df}=14, \mathrm{P}<$ 0.005 (figure 2) and $\mathrm{X}^{2}=3.441 \mathrm{df}=4, \mathrm{P}<0.05$ (figure 3 ) respectively. Birds are very important to the natural ecological sustainability, especially in the tropics where the rainforest is undergoing intensive depletion due to corruption and mismanagement of public funds. However, the touristic love for bird-watch on some species like weaver-birds has been controversial in wildlife conservation, due to the destructive role played some species of birds in croplands. The weaverbird feeding activity on maize (Zea mays), avocado (Persea americana), and oil palms (Elaeis guineensis) was significantly recorded in this study. Crop-farming in Buea municipality and other parts of Cameroon has been rendered difficult by the weaver-bird feeding activity, one of the main reasons for the low crop-yield in most cultivation seasons.

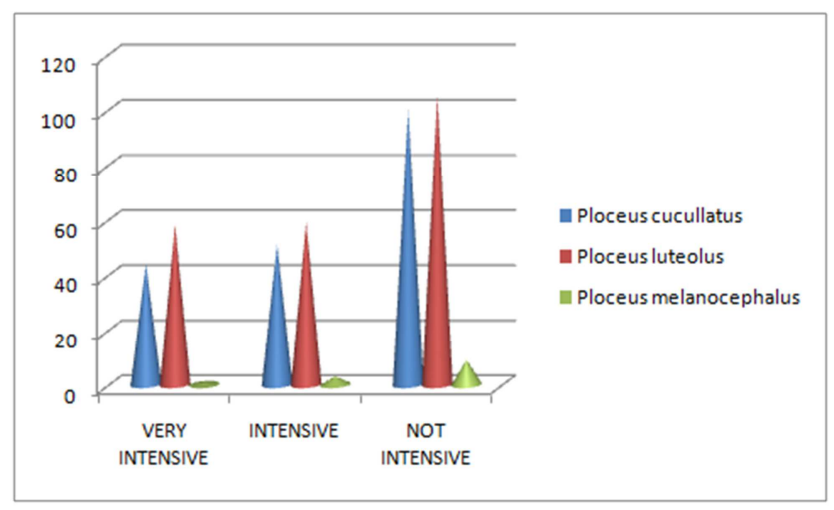

Figure 3. Weaver bird activity on cropland.

There was weaver-bird activity frequency of $51.63 \%$, $45.35 \%$, and $3.02 \%$ for Ploceus luteolus, Ploceus cuculatus, and Ploceus melanocephalus respectively (figure 4). These bird pests were not only frequent in the study area but are among the dominant bird pest in Cameroon and other countries in sub Saharan African region. The bird population is high and a nuisance to the local farming population, 
affecting their crop-farm yield on both seasonal and annual bases. The major problem farmers in the local and remote communities are facing is fighting the weaver-bird population. Unfortunately, the primitive approach involving the use of stone-throw, drumming, shouting, and hand-clap chasing rather seems to escalate their problems since weaverbirds would fly off to neighboring farmlands during the application of such methods.

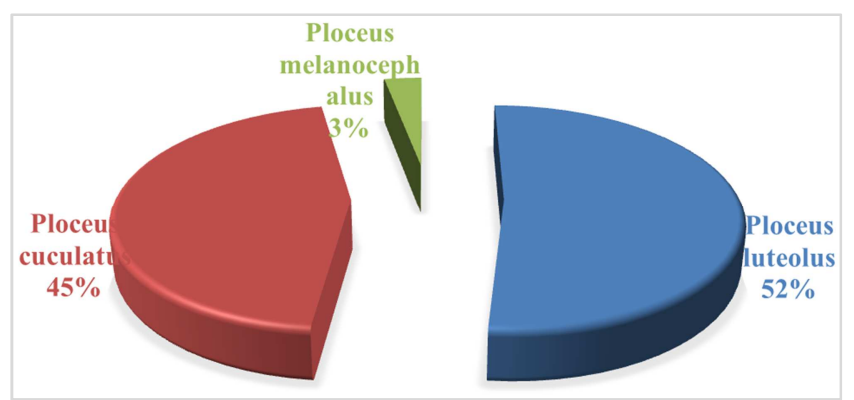

Figure 4. Frequency of weaver bird species.

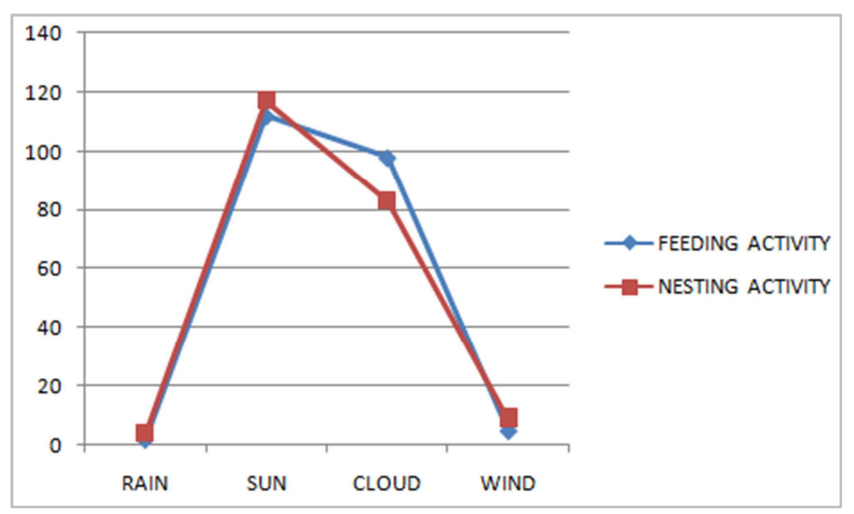

Figure 5. Bird activity and weather.

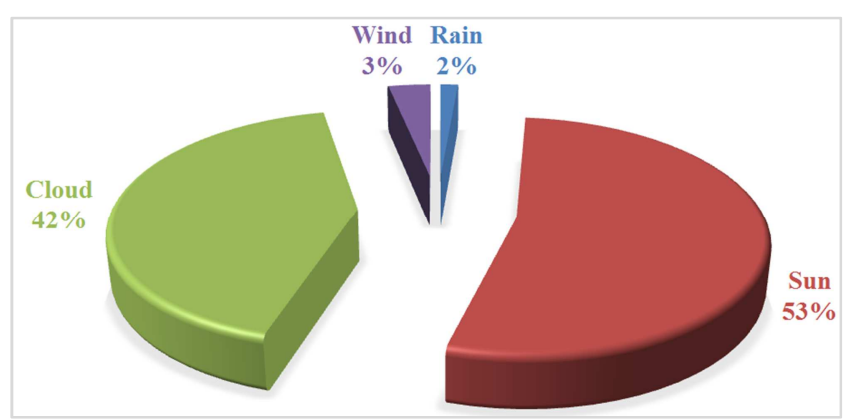

Figure 6. Frequency of activity and weather.

Additionally, a week association was recorded between birds' activity and weather, $\mathrm{X}^{2}=3.125 \mathrm{df}=3, \mathrm{P}<0.05$ (figure 5 ). The effect of atmospheric conditions has been well known on wildlife behavioral activity changes, influencing both the social and individual activities. The sunny and cloudy weather conditions recorded 53.26\%, and 42.09\% respectively, while the windy and rainy weather conditions were significantly low (3.26) (figure 6). It must also be noted that the turbulent atmospheric condition in mount Fako is characterized with heavy rainfall, wind, and cloud in most parts of the year. Hence, any sunny weather condition, especially in the rainy season is considered as an advantage to wildlife feeding activity. During heavy rains the birds were observed flying into their nests to shelter, waiting for a convenient atmosphere to intensify feeding and their nestbuilding.

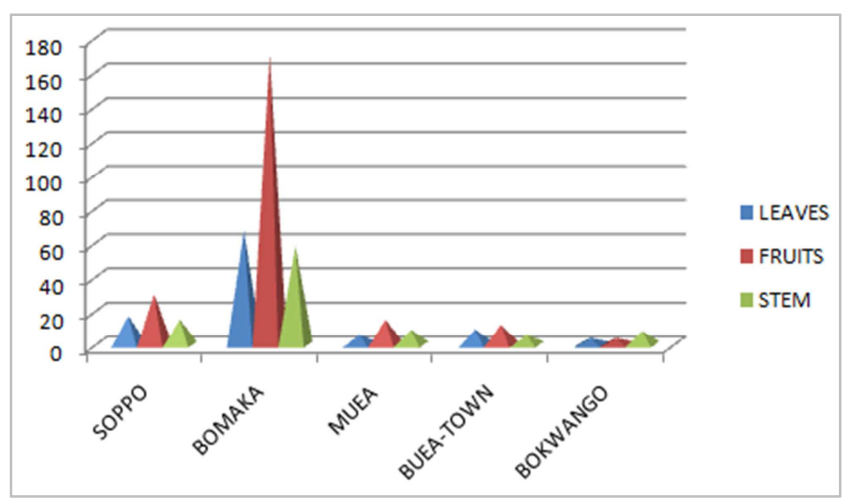

Figure 7. Human neighborhood and crop-portion destruction.

Furthermore, human neighborhood showed a significant association on crop species, $\mathrm{X}^{2}=42.253 \mathrm{df}=28, \mathrm{P}<0.05$ (figure 8). Crop species such as maize, avocado, and oil palms were the most affected in Bokwango, Buea-town, Muea, and Bomaka neighborhoods, while Soppo neighborhood was the least affected. Human neighborhood and foliage destruction revealed a significance, $\mathrm{X}^{2}=13.144$ $\mathrm{df}=8, \mathrm{P}<0.05$ (figure 7). Bomaka neighborhood still recorded the highest foliage destruction comparatively.

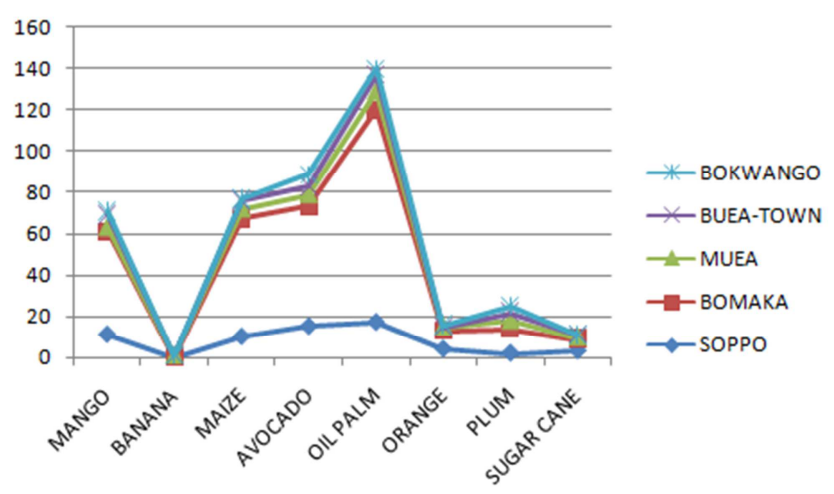

Figure 8. Human neighborhood and crop species.

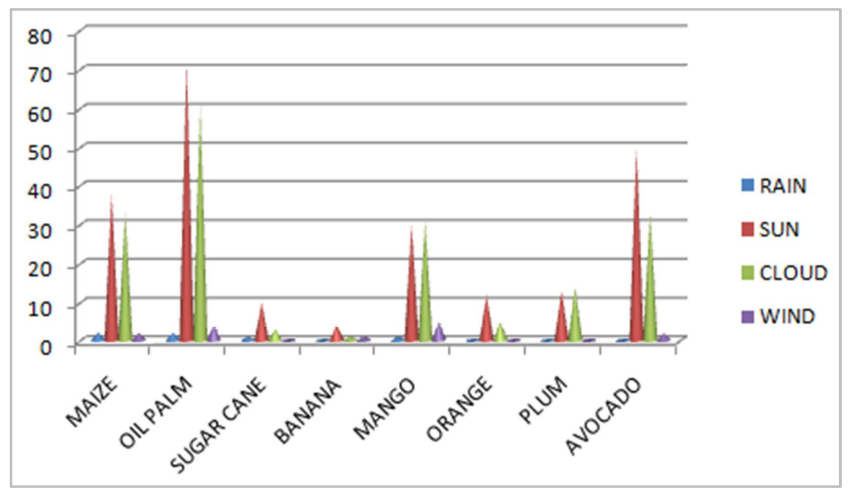

Figure 9. Atmospheric conditions and weaver-birds' activity on crops. 
An association was observed between atmospheric conditions and weaver-birds' activity on crops, $X^{2}=23.249$ $\mathrm{df}=21, \mathrm{P}<0.05$ (figure 9). Three weather types, wind, cloud, and sun remarkably favored the activity of birds on maize, avocado, and oil-palm while their activities were low during rainy weather condition. Maize and oil-palms were among the crop species most subjected to destruction by birds. These crops were observed with poor foliage formation and fruits, consequently they withered. Since the local farming population in this municipality is predominantly cultivating these crops most, a heavy toll is often taken on the farmers' annual farm-income. In addition, the most destroyed farms were Elaeis guineensis (32.33\%), Saccharum officinarum (19.77\%), Zea mays (17.44\%), and Mangifera indica $(15.58 \%)$ (figure 10$)$, and the scale of destruction was very prominent on the foliage used by these birds to build their nests.

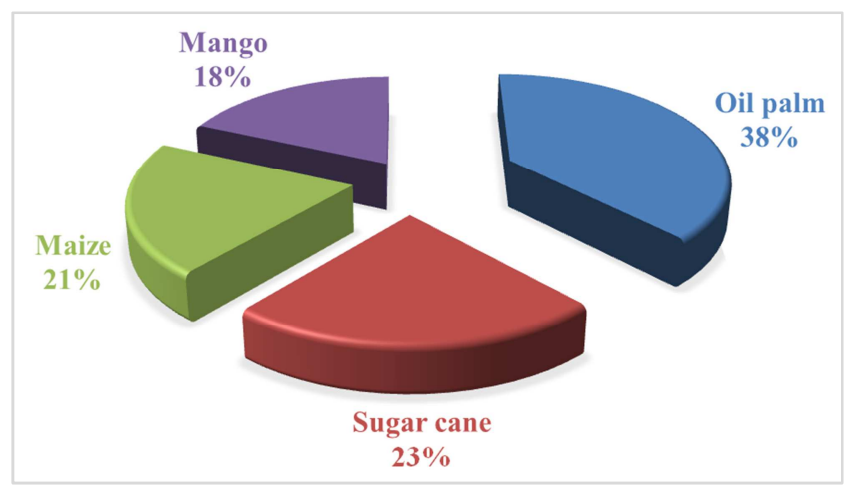

Figure 10. Frequency of farm destruction.

\section{Discussion}

Agricultural expansion into new areas and subsequent intensification of the production process brought associated impacts on bird habitats. Intensification of agriculture followed expansion, facilitated by the increased availability and use of synthetic nitrogen fertilizers and pesticides after WWII [3, 19]. Intensification can be described as taking a maximum proportion of primary production for human consumption, which results in less being available for the rest of nature [28]. Another characterization is that agricultural intensification is the use of practices that increase yields in the short term but that also typically result in land simplification and homogenization [10, 28]. Intensification normally means high-yielding crop varieties supported by applications of synthetic pesticides and fertilizers, mechanization, and often irrigation [28]. Intensification may also involve reduced crop diversity and simplified rotations, often monocultures, and land simplification through drainage and loss of non-crop areas [13, 10, 28, 8].

There are about 40 species of birds in North, East and Central Africa, which are considered as agricultural. Relatively a few number of all these species do appreciable damage to cultivated crops. Some bird species are extremely destructive, particularly to small grains as in the case of quelea and
Bishops. The activity pattern of birds in croplands is influenced by a number of factors such as crop type, non-crop physical structural arrangement and the agricultural practices $[37,7]$. Shift in cultivation timing also significantly affects the activity pattern of cropland birds, which causes further reduction of the population of farmland birds [25].

Home-garden agroforestry systems (HAS) are complex combinations of multilayered and multispecies vegetation patterns [27] thereby, providing an ideal forest-like habitat to conserve wildlife species by providing sufficient nesting, breeding, food and temporary refuge opportunities all year round [21]. These habitats are suitable for bird species, such as Common Pigeon (Columba livia), Spotted Dove (Spilopelia chinensis), House Sparrow (Passer domesticus), Scaly-breasted Munia (Lonchura punctulata), Common Myna (Acridotheres tristis), Baya Weaver (Ploceus philippinus), among others, which are human-tolerant and adjusted to human habitats. These birds have been usually found to build nests and forage for food in and around human settlements [43]. Their breeding season lasts from May to October [1]. During breeding season, the males moult into a yellow and brown nuptial plumage, while females remain pale brown [1]. They are granivorous birds forming enormous communal roosts [18, 12].

Birds select habitats that fit their requirements for successful reproduction and survival though some generalist species may utilize several habitats [36]. Differences in requirement among bird species have caused specificity on habitat requirement [6]. For example Mountain plover (Charadrius mountainus) feeds primarily on insects (grasshoppers, crickets, beetles, flies, ants); uses ground for nesting and prefer short grass while Mongolian sand plover (Charadrius atrifrons) feeds on invertebrates (molluscs, worms, crustaceans especially crabs and insects), uses tree for nesting and prefer shore of the lakes. Therefore, habitats either terrestrial or aquatic restrict bird species distribution and diversity [30]. In most habitats, plant communities determine the physical structure of the environment, and therefore, have a considerable influence on the distributions, abundance and diversity of birds and interactions of other animal species. For example, for bird species diversity in forests, [47] evidenced that the physical structure of a plant community, i.e. how the foliage is distributed vertically, may be more important than the actual composition of plant species. [36] Found that farmland also has been an important habitat for farmland bird showing that some bird species are habitat specific though some are generalist.

\section{Conclusion}

Green revolution has contributed in enhancing human population growth and distribution around the world. Unfortunately, it's done at the cost of the wild and our surrounding environment that we all depend. The consequence of fighting land space with wildlife is inevitable and it's the main reason wildlife population has suffered a severe decline over many decades. On the other hand local crop-farming 
areas have been molested by wildlife, especially weaver-birds known to be specialized on cereals, grains, fruits and foliage. Their nest-building activity and feeding on crop-farms have been a major problem faced by local crop-farmers in Cameroon and most parts of Africa. Reduction of the bird population on crop-land has given sleepless nights to both wildlife and agronomic researchers over years due to its prolific reproduction nature and its ability to cover long flight distances for crop-raiding. Though the bird population is not very high in southern Cameroon as compared to north, the damage on crop-farms is significantly embarrassing to the annual farm income of most farmers in places like Buea.

\section{References}

[1] Ali, S. \& S. D. Ripley (eds.) (1987). Compact Handbook of the Birds of India and Pakistan Together with those of Bangladesh, Nepal, Bhutan and Sri Lanka- 2 Nd Edition, Oxford University Press, Delhi, India.

[2] Askins RA, Chávez-Ramírez F, Dale BC, Haas CA, Herkert JR, Knopf FL, Vickery PD (2007) Conservation of grassland birds in North America: understanding ecological processes in different regions. Ornithol Monogr 64: 1-46

[3] Aspelin AL (2003) Pesticide usage in the United States: trends during the 20th century. NSF CIPM Technical Bulletin 105. Center for Integrated Pest Management, North Carolina State University, Raleigh.

[4] Bailey IE, Morgan KV, Oschadleus HD, DeRuiter SL, Meddle SL, Healy SD (2016) Nest-building males' trade of material collection costs with territory value. Emu 116: 1-8.

[5] Biddle LE, Deeming DC, Goodman AM (2015) Morphology and biomechanics of the nest of the Common Blackbird Turdus merula. Bird Study 62: 87-95.

[6] Bucklay HL, Freckleton RP (2020). Understanding the role of Species dynamics in abundant occupancy relationship, J Ecol. 98; 645-658.

[7] Burger A (1994) The agriculture of the world. Avebury/Ashgate Publishing Company, Aldershot.

[8] Butchart, S. H. M., Walpole, M., Collen, B., Van Strien, A., Scharlemann, J. P. W., Almond, R. E. A., Baillie, J. E. M., Bomhard, B., Brown, C., Bruno, J., Carpenter, K. E., Carr, G. M., Chanson, J., Chenery, A. M., Csirke, J., Davidson, N. C., Dentener, F., Foster, M., Galli, A., Galloway, J. N., Genovesi, P., Gregory, R. D., Hockings, M., Kapos, V., Lamarque, J. F., Leverington, F., Loh, J., McGeoch, M. A., McRae, L., Minasyan, A., Morcillo, M. H., Oldfield, T. E. E., Pauly, D., Quader, S., Revenga, C., Sauer, J. R., Skolnik, B., Spear, D., Stanwell-Smith, D., Stuart, S. N., Symes, A., Tierney, M., Tyrrell, T. D., Vié, J. C., \&Watson, R. (2010). Global biodiversity: indicators of recent declines. Science, 328, 1164-1168.

[9] Chazdon, R. L., Peres, C. A., Dent, D., Sheil, D., Lugo, A. E., Lamb, D., Stork, N. E., \& Miller S. (2009). The potential for species conservation in tropical secondary forests. Conservation Biology, 23, 1406-1417.

[10] Donald PF, Green RE, Heath MF (2001) Agricultural intensification and the collapse of Europe's farmland bird populations. Proc R Soc B 268: 25-29.

[11] Ekane N B, (2000). The Socio Economic Impact of Pronus Africana Management in the Mount Cameroon Region. Case study of the Bukwango Community. Presented as partial fulfilment of the degree of M Sc. From the department of Urban Planning and Environment, Royal Institute of Technology Stockholm.

[12] Ellis EC, Goldewijk KK, Siebert S, Lightman D, Ramankutty N (2010) Anthropogenic transformation of the biomes, 1700 to 2000. Glob Ecol Biogeogr 19: 589-606.

[13] Filippi-Codaccioni O, Devictor V, Bas Y, Clobert J, Julliard R (2010) Specialist response to proportion of arable land and pesticide input in agricultural landscapes. Biol Conserv 143: 883-890.

[14] Fitton, J. D., Kilburn, C. R. J., Thirwall, M. F., Hughes, D. J., (1983). 1982 eruption of Mt. Cameroon, West Africa. Nature $306,327 \mathrm{e} 332$.

[15] Flannery $\mathrm{T}$ (2001) The eternal frontier, an ecological history of North America and its peoples. Grove Press, New York.

[16] Foley JA, DeFries R, Asner GP, Barford C, Bonan G, Carpenter SR, Chapin FS, Coe MT, Daily GC, Gibbs HK, Helkowski JH, Holloway T, Howard EA, Kucharik CJ, Monfreda C, Patz JA, Prentice IC, Ramankutty N, Snyder PK (2005) Global consequences of land use. Science 309: 570 574.

[17] Fowler P (2002) Farming in the first millennium AD, British agriculture between Julius Caesar and William the conqueror. Cambridge University Press, Cambridge.

[18] Gadgil, M. \& S. Ali (1974). Communal roosting habits of Indian Birds. Journal of Bombay Natural History Society 72 (3): 716-727.

[19] Galloway JN, Aber JD, Erisman JW, Seitzinger SP, Howarth RW, Cowling EB, Cosby BJ (2003) The nitrogen cascade. Bioscience 53: 341-356

[20] Gibson, L., Lee, T. M., Koh, L. P., Brook, B. W., Gardner, T. A., Barlow, J., Peres, C. A., Bradshaw, C. J. A., Laurance, W. F., Lovejoy, T. E., \& Sodhi, N. S. (2011). Primary forests are irreplaceable for sustaining tropical biodiversity. Nature, 478, 378-383.

[21] Griffith, D. M. (2000). Agroforestry: A refuge for tropical biodiversity after fire. Conservation Biology14: 325-326.

[22] Grimm, N. B., Faeth, S. H., Golubiewski, N. E., Redman, C. L., Wu, J., Bai, X. \& Briggs, J. M. (2008). Global change and the ecology of cities. Science, 319, 756-760.

[23] Hansen MC, Stehman SV, Potapov PV, Loveland TR, Townshend JRG, DeFries RS, Pittman KW, Arunarwati B, Stolle F, Steininger MK, Carroll M (2008) Humid tropical forest clearing from 2000 to 2005 quantified by using multitemporal and multiresolution remotely sensed data. Proc Natl Acad Sci USA 105: 9439-9444.

[24] Herkert JR (2009) Response of bird populations to farmland set-aside programs. Conserv Biol 23: 1036-1040.

[25] Jobin, B., Des Granges, J. L., \& Boutin, C. (1996). Population trends in selected species of farmland birds in relation to recent developments in agriculture in the St. Lawrence Valley. Agriculture, Ecosystems \& Environment. 57, 103-116. 
[26] Kareiva, P., Watts, S., McDonald, R., \& Boucher, T. (2007). Domesticated nature: shaping landscapes and ecosystems for human welfare. Science, 316, 1866-1869.

[27] Kehlenbeck, K. \& B. L. Maass (2004). Crop diversity and classification of homegardens in Central Sulawesi, Indonesia. Agroforestry Systems63: 53-62.

[28] Krebs JR, Wilson JD, Bradbury RB, Siriwardena GM (1999) The second silent spring? Nature 400: 611-612.

[29] Larson G, Albarella U, Dobney K, Rowley-Conwy P, Schibler J, Tresset A, Vigne J-D, Edwards CJ, Schlumbaum A, Dinu A, Balaçsescu A, Dolman G, Tagliacozzo A, Manaseryan N, Meyer WB, Turner BL II (1992) Human population growth and global land-use/cover change. Annu Rev Ecol Syst 23: 39-61.

[30] Maclean G. L. (1970). The pygmy falcon (Polihierax semitorquatus). Koedoe 13, 1-20.

[31] Norris K (2008) Agriculture and biodiversity conservation: opportunity knocks. Conserv Lett 1:2-11.

[32] Piperno DR, Ranere AJ, Holst I, Iriarte J, Dickau R (2009) Starch grain and phytolith evidence for early ninth millennium BP maize from the Central Balsas River Valley, Mexico. Proc Natl Acad Sci USA 106: 5019-5024.

[33] Price TD (2009) Ancient farming in eastern North America. Proc Natl Acad Sci USA 106: 6427-6428.

[34] Pringle H (1998) The slow birth of agriculture. Science 282: $1446-1450$.

[35] Ranere AJ, Piperno DR, Holst I, Dickaua R, Iriarte J (2009) The cultural and chronological context of early Holocene maize and squash domestication in the Central Balsas River Valley, Mexico. Proc Natl Acad Sci USA 106: 5014-5018.

[36] Ranganathan, J., Chan, K. M. A., Daily, G. C., (2007). Satellite detection of bird communities in tropical countryside. Ecological Applications 17, 1499-1510.

[37] Rodenhouse, N. L., Best, L. B., O'Conner. \& Bollinger, E. K. (1995). Effect of agricultural Practices and farmland structure. In Ecology and management of neotropical birds: a synthesis and Review of critical issues T. E. Marrin and D. M. Finch (Eds.). Oxford University Press. New Yark. Pp. 269-293.

[38] Rodríguez-Estrella R (2007) Land use changes affect distributional patterns of desert birds in the Baja California peninsula, Mexico: Bird distribution and human activity in Baja California. Divers Distrib 13: 877-889.

[39] Rosenstock SS, Anderson DR, Giesen KM, Leukering T,
Carter MF (2002). Landbird counting techniques current practices and an alternative. The Auk 119: pg. 46, 48 pgs.

[40] Rowley-Conwy P (2009). Human prehistory: hunting for the earliest farmers. Curr Biol 19: R948-R949.

[41] Silva B, Correia J, Nunes F, Tavares P, Varum H, and Pinto J (2010) Bird nest construction-lessons for building with earth. WSEAS Trans Environ Dev 6: 82-92.

[42] Smith BD, Yarnell RA (2009) Initial formation of an indigenous crop complex in eastern North America at 3800 BP Proc Natl Acad Sci USA 106: 6561-6566.

[43] Soni, V. C., P. L. Sharma, S. M. Dave, K. Bhalodia \& V. Vijaykumar (2004). Nesting ecology of some terrestrial birds in Rajkot City (Gujrat). Current Bio Science1: 97-104.

[44] Spangenberg JE, Matuschik I, Jacomet S, Schiblerc J (2008) Direct evidence for the existence of dairying farms in prehistoric Central Europe (4th millennium BC). Isot Environ Health Stud 44: 189-200.

[45] Spurr EB (2005). Monitoring bird populations in New Zealand: a workshop to assess the feasibility of a national bird population monitoring scheme. In: Bezar C (ed.), Landcare Research Science Series No 28. Lincoln.

[46] Tanjong, E. (2014). Socio-economic survey of the villages of Mount Cameroon National Park (MCNP). Program for Sustainable Management of Natural Resources Cameroon South-West Region, Buea, Cameroon. 117: 529-38.

[47] Tewes, E., Terrasse, M., Sánchez, J. J., Fremuth, W. \& Frey, H. (2004). Action plan for the recovery and conservation of vultures on the Balkan Peninsula: activities and projects during 2002 and 2003, 1-36.

[48] UN, (2011). Global cooperation needed to protect pathways of migratory species, Head of UN-backed convention urges greater effort to combat illegal rhino trade, 10 November 2011.

[49] Vickery PD, Tubaro PL, Da Silva JMC, Peterjohn BG, Herkert JR, Cavalcanti RB (1999) Conservation of grassland birds in the western hemisphere. Stud Avian Biol 19: 2-26.

[50] Wilson JD, Evans AD, Grice PV (2009) Bird conservation and agriculture. Cambridge University Press, Cambridge.

[51] With KA, King AW, Jensen WE (2008) Remaining large grasslands may not be sufficient to prevent grassland bird declines. Biol Conserv 141: 3152-3167.

[52] Zeder MA (2008) Dom50ication and early agriculture in the Mediterranean Basin: origins, diffusion, and impact. Proc Natl Acad Sci USA 105: 11597-11604. 